\title{
LITISPENDÊNCIA E CONEXÃO NO PROCESSO COLETIVO BRASILEIRO
}

\section{Marcelo Henrique Matos Oliveira*}

Sumário: 1 Introdução; 2 Litispendência no Código de Processo Civil; 3 A conexão no Código de Processo Civil; 4 Legitimidade ativa nas ações coletivas; 5 Litispendência e conexão no âmbito do processo coletivo; 5.1 Identidade entre pedidos e/ou causa de pedir em ações coletivas - litispendência e extinção da ação; 5.2 Identidade entre pedidos e/ou causa de pedir em ações coletivas - conexão e reunião da ação; 5.3 Identidade entre pedidos e/ou causa de pedir em ações coletivas - litispendência e reunião da ação; 6 Considerações finais.

Resumo: O presente trabalho tem por objetivo o estudo dos efeitos da litispendência e da conexão no âmbito do processo coletivo. Ocorre que esses institutos foram criados à luz do processo civil clássico, de cunho eminentemente individualista, o que gera controvérsias e torna seu estudo complexo, especialmente por não estarem de acordo com os princípios específicos e a necessidade de um processo efetivo. Após a análise da doutrina e jurisprudência, foi demonstrada a necessidade da reunião das ações para o aproveitamento das provas colhidas e da situação jurídica apresentada, possibilitando um amplo acesso à justiça.

Palavras-chave: Ações coletivas. Litispendência. Conexão.

\footnotetext{
* Mestre em Direito Coletivo, Cidadania e Função Social pela Universidade de Ribeirão Preto. Membro do Instituto Brasileiro de Direito Processual - IBDP. Pós-Graduado em Direito Processual Civil pela Universidade Anhanguera - UNIDERP. Bacharel em Direito pela Universidade de Uberaba - UNIUBE. Professor Universitário. Advogado.
} 


\section{Introdução}

Ao estudar os contornos para a conceituação e compreensão dos institutos da litispendência e conexão, é necessário buscar fundamentação teórica no processo civil clássico. Todavia, sua aplicação no âmbito coletivo deve ser interpretada cum granum salis, na medida em que esses institutos foram idealizados apenas no século passado, influenciados pelo liberalismo.

O presente trabalho, ao analisar as teorias existentes, busca a solução que mais se coaduna com os aspectos fundamentais da efetividade do processo coletivo, recorrendo à pesquisa bibliográfica doutrinária em revistas e livros jurídicos, além da inclusão de material jurisprudencial, com o escopo de estabelecer a pesquisa acadêmica no âmbito da prática judiciária.

\section{Litispendência no Código de Processo Civil}

O termo litispendência indica "a situação jurídica em que encontra-se uma causa ao estar submetida ao julgamento e resolução dos tribunais". ${ }^{1}$

Esse instituto processual está previsto no artigo $301, \S \S 1^{\circ}, 2^{\circ}$ e $3^{\circ}$, do Código de Processo Civil. Ocorrerá sempre que dois ou mais processos idênticos existirem concomitantemente, caracterizando-se a identidade pela verificação no caso concreto da tríplice identidade (mesmas partes, mesma causa de pedir e mesmo pedido) ${ }^{2}$.

A litispendência nada mais é que uma defesa processual peremptória, fundada em dois importantes princípios: economia processual e harmonização de julgados. Sobre o tema, lecionam Luiz Rodrigues Wambier e Eduardo Talamini:

A existência de um processo pendente entre A e B, baseado numa determinada causa de pedir, que resulta no pedido $\mathrm{X}$, desempenha o papel de pressuposto processual negativo para um outro processo entre A e B, que tenha a mesma

1 GOLDSCHIMIDT, James. Direito processual civil. Tradução de Lisa Pary Scarpa. Campinas: Brookseler, 2003. tomo I, p. 384.

2 PROCESSUAL CIVIL E TRIBUTÁRIO - CONTRIBUIÇÃO SOCIAL - FINSOCIAL - AUMENTOS DAALÍQUOTA - INCONSTITUCIONALIDADE - COMPENSAÇÃO - LITISPENDÊNCIA - INOCORRÊNCIA - PRECEDENTES. A existência de litispendência pressupõe a tríplice identidade entre as partes, a causa de pedir e o pedido, pelo que não se há que falar nesse instituto se houver distinção em qualquer desses elementos. (...). Recurso conhecido e provido para afastar a decretada litispendência e determinar o julgamento do mérito na instância de origem." (REsp. 397.186/RS, Rel. Min. FRANCISCO PEÇANHAMARTINS, SEGUNDATURMA, DJ 07/11/2005) 
causa de pedir e em que se formule o mesmo pedido. O fundamento desse pressuposto processual negativo está no princípio da economia processual e na necessidade de se evitarem julgamentos conflitantes. ${ }^{3}$

É interessante transcrever as palavras de Chiovenda sobre a litispendência: "em geral, indica a pendência de uma relação processual na plenitude de seus efeitos." "4

Observe que não há qualquer razão para a manutenção de dois processos idênticos, onde será despendida energia desnecessária com a duplicação de atos. Além disso, a manutenção de processos idênticos poderá levar a decisões contraditórias, o que acarreta insegurança jurídica e desprestígio ao Poder Judiciário.

A consequência processual é a extinção de um dos processos, sem resolução de mérito. Para determinar qual será extinto, aplica-se a regra do artigo 219 ou do artigo 106, ambos do CPC. Assim, caso as ações tramitem em comarcas diferentes, a ação que será extinta é aquela em que ocorreu por último a citação válida, regra do artigo 219. Por outro lado, se tramitarem na mesma comarca, será extinta a ação que tenha sido despachada ${ }^{5}$ em último lugar.

O réu deverá alegar a litispendência na contestação ou na primeira oportunidade em que falar nos autos, sob pena de responder pelas custas, a que seu retardamento der causa. $\mathrm{O}$ juiz também poderá conhecer de ofício tais matérias, conforme o artigo 267, §3, do Código de Processo Civil.

Por se tratar de extinção sem resolução do mérito, o reconhecimento da litispendência impede que o autor reproponha a ação. Segundo Humberto Theodoro Júnior, "embora não se trate de sentença de mérito, sua força é equivalente à da coisa julgada material." 6

Ressalte-se que pouco importa o nome que tenha sido dado à ação. Segundo José Miguel Garcia Medina (2010), "podem as ações ter nomes ou ritos diferentes ou iguais, mas o que importará será a presença dos três elementos, acima referidos."

3 WAMBIER, Luiz Rodrigues; TALAMINI, Eduardo. Curso avançado de processo civil: Teoria Geral do Processo e Processo de Conhecimento. 11. ed. São Paulo: Revista dos Tribunais, 2010, p. 212.

4 CHIOVENDA, Giuseppe. Instituições de direito processual civil. Tradução de Paolo Capitanio. 2. ed. Campinas: Bookseller, 2000. v. 1, p. 282.

5 Despachar em primeiro lugar significa pronunciamento judicial positivo que determina a citação, não terá o mesmo efeito o despacho que busque emendar a inicial.

6 THEODORO JÚNIOR, Humberto. Curso de direito processual civil. 42. ed. Rio de Janeiro: Forense, 2005. v. 1, p. 288. 
Assim, por exemplo, mesmo entre embargos à execução e ação de conhecimento movida autonomamente pelo devedor contra o credor, pode dar-se a litispendência:

TRIBUTÁRIO E PROCESSUAL CIVIL. RECURSO ESPECIAL. OMISSÃO NÃO CONFIGURADA. MENOR ONEROSIDADE. AUSÊNCIA DE PRÉQUESTIONAMENTO. EXECUÇÃO FISCAL E AÇÃO ANULATÓRIA DO DÉBITO. CONEXÃO. REUNIÃO DOS PROCESSOS. (...) 3. Se é certo que a propositura de qualquer ação relativa ao débito constante do título não inibe o direito do credor de promover-lhe a execução (CPC, art. 585, § $1^{\circ}$ ), o inverso também é verdadeiro: o ajuizamento da ação executiva não impede que o devedor exerça o direito constitucional de ação para ver declarada a nulidade do título ou a inexistência da obrigação, seja por meio de embargos (CPC, art. 736), seja por outra ação declaratória ou desconstitutiva. Nada impede, outrossim, que o devedor se antecipe à execução e promova, em caráter preventivo, pedido de nulidade do título ou a declaração de inexistência da relação obrigacional. 4. Ações dessa espécie têm natureza idêntica à dos embargos do devedor, e quando os antecedem, podem até substituir tais embargos, já que repetir seus fundamentos e causa de pedir importaria litispendência. ${ }^{7}$

Outro ponto importante é que, segundo a doutrina majoritária, a existência de um processo estrangeiro não obsta a existência de um processo idêntico em território nacional, e vice-versa. Nesse sentido, é a lição de Humberto Theodoro Júnior: "a litispendência é fenômeno típico da competência interna, de sorte que nunca ocorre entre causas ajuizadas no país e no exterior."

Por fim, cabe destacar qual é o momento em que se configura a litispendência. Para Cândido Rangel Dinamarco, ela ocorre com a propositura da demanda, ou seja, considera-se o processo pendente a partir do momento em que a petição inicial é entregue ao judiciário até o momento em que não é mais cabível qualquer recurso. ${ }^{8}$

José Frederico Marques, no mesmo sentido, argumenta: "com a propositura da ação o litígio adquire tonalidade processual e, em torno da área demarcada pelo pedido do autor, forma-se a litispendência."

No entanto, a doutrina majoritária afirma que a litispendência ocorre com a realização da citação válida do réu, pois é nesse momento que se vislumbra a formação da relação processual. André de Luizi Correia salienta que antes desse momento não há relação jurídica processual, "mas apenas início de

7 STJ, REsp 899.979/SP, $1^{\circ}$ T., j. 23.09.2008, Rel. Min. Teori Albino Zavascki, Dje 01.10.2008.

8 DINAMARCO, Cândido Rangel. Instrumentalidade do processo. São Paulo: Revista dos Tribunais, 1990, p. 49.

9 MARQUES, José Frederico. Instituições de direito processual civil. Rio de Janeiro: Forense, 1958. v. 3, p. 212. 
processo, que não se presta a produzir nenhum dos efeitos encartados no art. 219 , nem com relação ao autor, nem com relação ao réu."

\section{A conexão no Código de Processo Civil}

A conexão está prevista no artigo 103 do Código de Processo Civil: "Reputam-se conexas duas ou mais ações, quando lhes for comum o objeto ou a causa de pedir".

Não se deve confundir o fenômeno da conexão com a sua consequência, ou seja, com o seu efeito, que será a reunião dos processos perante um só juízo para julgamento conjunto. Como se sabe, "o conteúdo não se confunde com o efeito, até mesmo porque o efeito de um instituto é fenômeno externo a ele, enquanto o conteúdo pertence ao seu interior". ${ }^{11}$

O objetivo do processo é a composição dos conflitos de interesse, cujos elementos essenciais são os sujeitos, o objeto e a causa de pedir. O que evidencia a conexão entre as demandas é a identidade parcial dos elementos da lide deduzida nos diversos processos.

Segundo Humberto Theodoro Júnior, o código admite duas modalidades de conexão: pelo objeto comum e pela mesma causa de pedir. A primeira forma ocorre quando nas diversas lides se disputa o mesmo objeto, como, por exemplo, no caso de duas ações voltadas, separadamente, contra dois coobrigados por uma mesma dívida. A segunda forma se baseia na identidade de causa petendi que ocorre quando as várias ações tenham por fundamento o mesmo fato jurídico. ${ }^{12}$

O objetivo da norma inserta no artigo 103 é evitar contradições nas decisões proferidas pelo Poder Judiciário, por isso, a indagação sobre o objeto ou a causa de pedir deve ser interpretada de modo a permitir a decisão unificada.

A existência de decisões conflitantes em litígios que tratem de situações semelhantes é, naturalmente, motivo de descrédito e causa de insegurança jurídica.

Em outras palavras, Rodolfo de Camargo Mancuso argumenta que "os pleitos iguais, dentro de um mesmo contexto social e histórico, não devem ter

${ }^{10}$ CORREIA, André de Luizi. A citação no direito processual civil brasileiro. São Paulo: Revista dos Tribunais, 2001.

11 NEVES, Daniel Amorim Assumpção. Manual de processo civil. 2. ed. São Paulo: Método, 2010, p. 151 .

12 THEODORO JÚNIOR, Humberto. Curso de direito processual civil. 42. ed. Rio de Janeiro: Forense, 2005. v. 1, p. 168-169. 
soluções diferentes. Aopinião leiga não compreende a contrariedade dos julgados, nem o comércio jurídico a tolera, pelo seu natural anseio de segurança." ${ }^{13}$

Além de evitar decisões contraditórias, essa norma tem o escopo de acolher o Princípio da Economia Processual, tornando possível resolver, de uma única vez, várias lides, inclusive podendo utilizar o mesmo material probatório. ${ }^{14}$

Outra questão refere-se à obrigatoriedade ou facultatividade na reunião de processos em razão da conexão. Segundo o artigo 105 do Código de Processo civil, "o juiz, de ofício ou a requerimento de qualquer das partes, pode ordenar a reunião de ações propostas em separado, a fim de que sejam decididas simultaneamente".

Observa que, em análise literal do dispositivo legal, trata-se de opção do magistrado a decisão pela reunião ou não dos processos. Essa é a lição de Hélio Tornaghi ${ }^{15}$, que assevera ser da conveniência do julgador a adoção de tal providência.

Todavia, Luiz Manoel Gomes Júnior ${ }^{16}$ afirma que ainda que não exista necessidade de reunião dos processos, sob o aspecto fático, a distribuição por dependência é obrigatória, sem qualquer margem para decisão em sentido contrário.

Em que pese essa celeuma, a reunião que não possa alcançar o objetivo traçado para o instituto não deve ocorrer. Repudia-se, dessa forma, a reunião automática. Esse parece ser o escopo da súmula 235 do Superior Tribunal de Justiça ${ }^{17}$, que veda a reunião de processos quando um deles estiver no tribunal, vez que em um deles a prova já foi produzida e a decisão já foi prolatada, não havendo economia ou harmonização dos julgados que favoreça a reunião.

Dessa forma, foram traçadas as principais características dos institutos da litispendência e da conexão, à luz do Processo Civil Clássico, que servirão para uma melhor análise de sua aplicação no processo coletivo, sobretudo diante da autonomia principiológica existente, sempre em busca da economia processual e efetividade dos julgados.

${ }^{13}$ MANCUSO, Rodolfo de Camargo. Divergência jurisprudencial e súmula vinculante. São Paulo: Revista dos Tribunais, 1999, p. 18.

${ }^{14}$ GOMES JUNIOR, Luiz Manoel. Curso de direito processual civil coletivo. 2. ed. São Paulo: Srs, 2008, p. 186.

15 TORNAGHI, Hélio. Comentários ao código de processo civil. São Paulo: Revista dos Tribunais, 1974, p. 347.

${ }^{16}$ GOMES JUNIOR, Luiz Manoel. Curso de direito processual civil coletivo. 2. ed. São Paulo: Srs, 2008, p. 188.

${ }^{17}$ Súmula 235 do Superior Tribunal de Justiça: A conexão não determina a reunião dos processos, se um deles já foi julgado. 


\section{Legitimidade ativa nas ações coletivas}

Segundo Liebman, a legitimidade é a individualização da pessoa a quem pertence o interesse de agir e da pessoa em relação à qual esse interesse existe: "decorre da distinção entre a existência objetiva do interesse de agir e a sua pertinência subjetiva" ${ }^{18}$. Isto é, quando a lei processual exige a presença do interesse de agir como condição para o exercício do direito de ação, exige também que ele exista na pessoa daquele que pode formular uma pretensão.

Em que pese esse posicionamento ainda ser sustentável no âmbito do processo individual, não deve ser aplicado de forma ampla à tutela coletiva. Em outras palavras, o conceito de legitimidade apresentado pela teoria eclética de Liebman não deve ser aplicado de forma ampla, por não contemplar a legitimidade para as ações coletivas, uma vez que só reconhece a legitimidade quando o titular da ação for o mesmo do direito material. Isso porque nas ações em que se pleiteiam direitos transindividuais, por vezes, o ente legitimado age como substituto processual, ou seja, em nome próprio na defesa de direito alheio.

O artigo 82, parágrafo único, do Código de Defesa do Consumidor, estabelece o seguinte rol:

Art. 82. Para os fins do art. 81, parágrafo único, são legitimados concorrentemente: (Redação dada pela Lei $n^{\circ}$ 9.008, de 21.3.1995)

I - o Ministério Público,

II - a União, os Estados, os Municípios e o Distrito Federal;

III - as entidades e órgãos da Administração Pública, direta ou indireta, ainda que sem personalidade jurídica, especificamente destinados à defesa dos interesses e direitos protegidos por este código;

IV - as associações legalmente constituídas há pelo menos um ano e que incluam entre seus fins institucionais a defesa dos interesses e direitos protegidos por este código, dispensada a autorização assemblear.

De igual modo, o artigo $5^{\circ}$ da Lei de Ação Civil Pública arrola os legitimados para a propositura da Ação Civil Pública:

Art. $5^{\circ}$ Têm legitimidade para propor a ação principal e a ação cautelar: (Redação dada pela Lei n ${ }^{\circ} 11.448$, de 2007).

I - o Ministério Público;

II - a Defensoria Pública;

${ }^{18}$ LIEBMAN, Enrico Tullio. Manual de direito processual civil. Tradução de Cândido Rangel Dinamarco. 3. ed. São Paulo: Malheiros, 2005. v. 1, p. 208. 
III - a União, os Estados, o Distrito Federal e os Municípios;

IV - a autarquia, empresa pública, fundação ou sociedade de economia mista; $\mathrm{V}$ - a associação que, concomitantemente:

a) esteja constituída há pelo menos 1 (um) ano nos termos da lei civil;

b) inclua, entre suas finalidades institucionais, a proteção ao meio ambiente, ao consumidor, à ordem econômica, à livre concorrência ou ao patrimônio artístico, estético, histórico, turístico e paisagístico.

Em 15 de janeiro de 2007, a Lei ${ }^{\circ} 11.448$ alterou o artigo $5^{\circ}$ da lei de Ação Civil Pública para acrescentar a legitimidade da Defensoria Pública. Essa alteração veio para consolidar o entendimento jurisprudencial que há tempos já previa tal possibilidade.

A legitimação nas demandas coletivas é exclusiva, pois só são legitimados à propositura dessas ações aqueles indicados na lei ou no ordenamento jurídico. Essa legitimação é autônoma, vez que não depende de qualquer autorização dos titulares do direito material posto em causa. Também é concorrente, na medida em que possibilita qualquer co-legitimado a propositura dessas ações, ou até mesmo a ingressar como assistente em litisconsórcio. E, por fim, é disjuntiva ou simples, já que os co-legitimados poderão figurar sozinhos na demanda, não sendo necessário o ajuizamento em conjunto da ação.

\section{Litispendência e conexão no âmbito do processo coletivo}

A possibilidade de serem instaurados vários processos coletivos que veiculam a mesma matéria tem se tornado cada vez mais frequente $\mathrm{e}$ problemática. Por exemplo, duas ações civis públicas, sendo uma delas movidas pelo Ministério Público e a outra por uma associação, onde se pleiteiam a defesa dos consumidores lesados por uma determinada empresa.

A ausência de norma que disciplina os institutos da litispendência e conexão no âmbito coletivo obriga os operadores do direito a buscarem embasamento legal no processo individual.

José Miguel Garcia Medina nota que, por um lado, a relação entre demandas coletivas se aproxima do instituto da conexão, vez que não há identidade de partes processuais, embora estejam presentes os mesmos pedidos e as causas de pedir das duas ações. Por outro lado, parece ajustarse melhor ao instituto da litispendência, pois a titularidade do direito material posto em juízo é a mesma nas duas ações. ${ }^{19}$

${ }^{19}$ MEDINA, José Miguel Garcia; WAMBIER, Teresa Arruda Alvim. Processo civil moderno: Parte Geral e Processo de Conhecimento. São Paulo: Revista dos Tribunais, 2010, p. 113. 
De qualquer forma, é afirmado que não há um regramento específico que contorne adequadamente o problema do relacionamento entre essas demandas, principalmente por se tratar de direitos transindividuais que, por vezes, não comporta as soluções encontradas pelo legislador ao processo individual.

Em outras palavras, a adaptação criativa do processo individual ao coletivo funciona até certo ponto, porque é indispensável a perseguição do ideal de se obter uma sistemática processual exclusiva para os processos coletivos, dadas as suas atuais singularidades, tanto em sua natureza como na finalidade, e que os afasta dos processos individuais em temas fundamentais como a coisa julgada, execução, procedimento, litispendência, conexão, dentre outros. Corroborando assevera Luiz Guilherme Marinoni e Sérgio Cruz Arenhart:

A sociedade moderna abre oportunidade a situações em que determinadas atividades podem trazer prejuízos aos interesses de grande número de pessoas, fazendo surgir problemas ignorados nas demandas individuais. O risco de tais lesões, que afetam simultaneamente inúmeros indivíduos ou categorias inteiras de pessoas, constitui fenômeno cada vez mais amplo e frequente na sociedade contemporânea. Ora, se a sociedade atual é caracterizada por ser de produção e consumo de massa, é natural que passem a surgir conflitos de massa e que os processualistas estejam cada vez mais preocupados em configurar um adequado "processo civil coletivo" para tutelar os conflitos emergentes. (...) É preciso, pois, para bem operar com as ações coletivas, despir-se de velhos preconceitos (ou pré-conceitos), evitando recorrer a raciocínios aplicáveis apenas à "tutela individual" para solucionar questões atinentes à tutela coletiva, que não é, e não pode ser, pensado sob a perspectiva da teoria da ação individual. Os institutos que presidem essa ação (ao menos em sua grande maioria) são incompatíveis e inaplicáveis à tutela coletiva, simplesmente porque foram concebidos para operar em outro ambiente. ${ }^{20}$

Diante dessas peculiaridades, parcela da doutrina que tenta superar esses problemas argumenta que o melhor caminho seria a reunião das ações para privilegiar os princípios da economia processual, do acesso à justiça, dentre outros. Todavia, ainda há aqueles que defendem a extinção de tais processos, entendendo tratar-se de litispendência, como se verá adiante.

${ }^{20}$ MARINONI, Luiz Guilherme; ARENHART, Sérgio Cruz. Manual do Processo de Conhecimento. 2. ed. São Paulo: Revista dos Tribunais, 2003, p. 749-751. 


\subsection{Identidade entre pedidos e/ou causa de pedir em ações coletivas - litispendência e extinção da ação}

A doutrina majoritária reconhece que em causas coletivas não é exigida a identidade da parte autora para a configuração da litispendência, bastando que haja identidade de pedido e da causa de pedir. Entretanto, nem todos que a defendem reconhecem os mesmos efeitos aplicados ao processo individual, ou seja, a extinção do processo litispendente.

Dentre os autores que asseveram a necessidade de extinção da ação estão Fredie Didier Júnior e Hermes Zaneti Júnior. Segundo eles, a litispendência no plano coletivo é igual ao que ocorre no plano individual: "não pode haver dúvidas de que a identificação dos elementos da ação, entre ações coletivas, impede o prosseguimento da ação coletiva ulterior". ${ }^{21}$

Também é a opinião de Antônio Gidi, que assegura:

É preciso ressaltar que, se entre uma ação coletiva do CDC e uma ação civil pública, uma ação popular, um mandado de segurança coletivo ou qualquer outra ação coletiva, ocorrer a identidade de causa de pedir e de pedido, haverá litispendência entre essas duas ações. Serão a mesma e única ação coletiva, apenas propostas com base em leis processuais diferentes. ${ }^{22}$

Adiante, o mesmo autor afirma que, no caso de tramitação concomitante de duas ações coletivas, o conflito é evidente, podendo apenas uma delas prosperar. No caso, poderia a parte autora do processo extinto intervir no processo remanescente como assistente litisconsorcial:

É preciso, pois, encontrar, no sistema do direito positivo brasileiro, solução para esse inconveniente: a) de lege lata, a interpretação mais correta do sistema, para a solução do impasse criado pela existência de "duas" ações coletivas "idênticas" (com mesmas partes, no sentido acima, mesma causa de pedir e mesmo pedido), contemporaneamente em curso (rectius: é a mesma ação, e não duas idênticas), é a aplicação dos dispositivos do CPC no que toca à matéria, mesmo porque assim dispõe, expressamente, o próprio CDC (art. 93, II, in fine). [...] No caso de duas ações coletivas, o potencial conflito é evidente, pelo que somente uma dessas ações deve prosperar. E nem seria de se esperar o prosseguimento de duas ações coletivas exatamente com o mesmo fim. [...] Desse modo, impõe-se que seja extinto o segundo processo, naquilo que coincidir com o primeiro, prosseguindo o feito no juízo prevento. À entidade autora do processo extinto resta, apenas, a possibilidade de intervir no processo remanescente como assistente litisconsorcial. ${ }^{23}$

${ }^{21}$ DIDIER JUNIOR, Fredie; ZANETI JUNIOR, Hermes. Curso de direito processual civil: Processo coletivo. 3. ed. Bahia: Podivm, 2008, p. 177.

${ }^{22}$ GIDI, Antonio. Coisa julgada e litispendência em ações coletivas. São Paulo: Saraiva, 1995, p. 219.

${ }^{23}$ GIDI, Antonio. Coisa julgada e litispendência em ações coletivas. São Paulo: Saraiva, 1995, p. 223-224. 
Kazuo Watanabe dispõe que é suficiente uma só demanda coletiva para a proteção de todas as pessoas titulares de direitos coletivos:

Se o que expõe o autor da demanda coletiva como causa de pedir, no aspecto ativo, são os interesses ou direitos 'difusos' ou 'coletivos', cujas notas características são as acima ressaltadas, dentre as quais sobressaem a natureza transindividual e o caráter indivisível e, no aspecto passivo, a violação desses mesmos interesses ou direitos, e se formula ele o pedido de tutela coletiva desses interesses ou direitos transindividuais e indivisíveis, é suficiente uma só demanda coletiva para a proteção de todas as pessoas titulares desses interesses ou direitos, 'indeterminadas e ligadas por circunstâncias de fato', em se tratando dos 'difusos' e de todas as pessoas pertencentes a um mesmo grupo, categoria ou classe 'ligadas entre si ou com a parte contrária por uma relação jurídica base', em se cuidando dos 'coletivos'. O mesmo se pode dizer em relação a 'interesses ou direitos individuais homogêneos', quanto ao processo de conhecimento da demanda coletiva (art. 95, CDC), tanto que a sentença procedente fará coisa julgada erga omnes, como dispõe o art. 103, III, do CDC. ${ }^{24}$

Para Elton Venturi, que também mantém a mesma linha de pensamento dos autores supramencionados, o ajuizamento de inúmeras ações coletivas, ainda que de espécies diferentes (Ação Popular, Ação Civil Pública, etc.), em que se pleiteiam pretensões idênticas, não poderá afastar a realidade de serem, antes e mais que conexas, essencialmente idênticas, ensejando a extinção da ação pelo reconhecimento da litispendência. ${ }^{25}$

Ressalte-se, ainda, o posicionamento de Teresa Arruda Alvim Wambier, para quem:

proposta a mesma ação coletiva perante juízo prevento, este deverá verificar se está diante de causas conexas - hipótese em que as ações deverão ser reunidas, para julgamento conjunto - ou se há litispendência, e neste caso a segunda ação deverá ser extinta. ${ }^{26}$

O entendimento apresentado é coerente com o processo civil clássico de onde se busca embasamento, mas, como salientado, em alguns pontos não poderá ser transportado para o processo coletivo, principalmente diante da importância, complexidade e dos princípios específicos que o regem.

${ }^{24}$ WATANABE, Kazuo. Demandas coletivas e os problemas da práxis forense. Revista de Processo, São Paulo, n. 67, jul./set. 1992, p. 18-19.

${ }^{25}$ VENTURI, Elton. Processo civil coletivo: A tutela jurisdicional dos direitos difusos, coletivos e individuais homogêneos no Brasil. Perspectivas de um Código Brasileiro de Processos Coletivos. São Paulo: Malheiros, 2007, p. 334.

${ }^{26}$ WAMBIER, Teresa Arruda Alvim. Litispendência em Ações Coletivas. In: MAZZEI, Rodrigo; NOLASCO, Rita Dias (Coord.). Processo civil coletivo. São Paulo: Quartier Latin, 2005, p. 287. 
É por isso que a tendência moderna refuta a extinção da ação litispendente, não só pela possibilidade de gerar prejuízos à coletividade, mas também pela busca da tutela jurisdicional adequada.

\title{
5.2 Identidade entre pedidos e/ou causa de pedir em ações coletivas - conexão e reunião da ação
}

Parcela minoritária da doutrina não vislumbra a possibilidade de se aplicar o instituto da litispendência, já que não existe a presença de todos os elementos da ação, tais como as partes, a causa de pedir e o pedido. Dentre eles, encontra-se José dos Santos Carvalho Filho, que dispõe:

\begin{abstract}
A litispendência é repetição de ação idêntica e exige as mesmas partes, a mesma causa de pedir e o mesmo pedido (art. $301 . \S \S 1^{\circ}$ e $2^{\circ}$, do CP Civil). São, pois, pressupostos da litispendência a repetição de ação idêntica e a circunstância de estar ainda pendente o processo anterior. Ora, não havendo essa identidade, não se configura a litispendência, mas sim a conexão, devendo os feitos reunir-se para um só julgamento. ${ }^{27}$
\end{abstract}

Através desse entendimento, jamais poderá haver litispendência entre a ação civil pública e a ação popular porque os autores são diversos. A rigor, só ocorrerá em relação a duas ações civis públicas ou duas ações populares, assim mesmo com pouca probabilidade. Exemplo seria a de um cidadão propor duas ações populares idênticas ou determinada associação propor duas ações civis públicas em face do mesmo réu e com causa de pedir e pedidos idênticos.

Entretanto, é possível ocorrer o fenômeno da conexão entre a ação civil pública e a ação popular, mesmo que possuam pedidos diversos, desde que haja identidade da causa petendi. Nos moldes do artigo 103 do Código de Processo Civil, é suficiente a identidade de causa de pedir ou de pedido para que seja reconhecida a conexão, cuja consequência será a reunião das ações.

O Superior Tribunal de Justiça já se manifestou a respeito no seguinte aresto:

AÇÃO CIVIL PÚBLICA. AÇÃO POPULAR. Inexistentes os pressupostos necessários à caracterização da litispendência, impõe-se afastá-la (CPC art. $301, \S 2^{\circ}$ ). Caracteriza-se, na hipótese, o instituto da conexão, já que as ações

${ }^{27}$ CARVALHO FILHO, José dos Santos. Ação civil pública: Comentários por artigo (Lei n ${ }^{\circ} 7.347$, de 24/7/85). 7. ed. Rio de Janeiro: Lumen Juris, 2009, p. 60. 
têm a mesma finalidade, o que as torna semelhantes e passíveis de decisões unificadas, devendo-se evitar julgamentos conflitantes sobre o mesmo tema, objeto das lides. ${ }^{28}$

Outro argumento relevante utilizado por aqueles que defendem tal entendimento é que a extinção do processo litispendente ofenderia o direito fundamental de acesso ao judiciário, como estabelecido no artigo $5^{\circ}, \mathrm{XXXV}$, da Constituição Federal, visto que o autor, fora das hipóteses expressas contidas na lei processual, tem direito de ver seu problema solucionado pelo Poder Judiciário.

Esse posicionamento é criticável principalmente por restringir o conceito de parte. Não há dúvidas que em se tratando de demanda onde se pleiteia Direito Coletivo não há que ser levado em conta a figura do autor para fins de reconhecimento de identidade de ações, pois o autor, em tais casos, atua como verdadeiro substituto processual, pleiteando não direito próprio, mas direito alheio, de toda a coletividade. Nesse sentido é a posição de Antônio Gidi:

Poder-se-ia argumentar que não haveria litispendência entre duas ações coletivas em defesa de um mesmo direito material, se interpostas por diferentes legitimados (dentre aqueles constantes no art. $5^{\circ}$ da LACP ou art. 82 do CDC). Afinal, dir-se-ia, ainda que a causa de pedir e o pedido sejam os mesmos, as partes não o seriam. Em que pese o fato de as pessoas não serem empiricamente as mesmas, entendemos que, para efeito de legitimidade, litispendência, efeitos da sentença e sua imutabilidade (autoridade da coisa julgada), juridicamente, trata-se da mesma parte. Por outro giro, as partes são consideradas as mesmas pelo direito positivo, muito embora, empiricamente, no mundo naturalístico, não o sejam. ${ }^{29}$

Pedro da Silva Dinamarco, de igual forma, assevera:

Os co-legitimados que figuram na relação jurídica processual para proteger interesses alheios (substituto processual) são as partes apenas no aspecto formal. A parte material, na realidade, são todos os substituídos, geralmente ausentes na relação processual. ${ }^{30}$

${ }^{28}$ REsp 208.680, 2a ${ }^{\mathrm{a}}$ Turma, Rel. Min. Francisco Peçanha Martins, julg. Em 6.4.2004, Dj de $31 / 05 / 2004$.

${ }^{29}$ GIDI, Antonio. Coisa julgada e litispendência em ações coletivas. São Paulo: Saraiva, 1995, p. 218-219.

30 DINAMARCO, Pedro da Silva. Competência, conexão e prevenção nas ações coletivas. In: MILARÉ, Edis (Coord.). Ação civil pública após 20 anos: efetividade e desafios. São Paulo: Revista dos Tribunais, 2005, p. 513. 
Assim, para fins de determinação dos elementos da demanda que verse sobre direitos transindividuais, pouco importa quem seja a pessoa que a propõe, uma vez que jamais será suficiente para converter um direito coletivo em individual.

Luiz Manoel Gomes Júnior, na primeira edição de sua obra Curso de Direito Processual Civil Coletivo, posicionava-se a favor da conexão quando os entes legitimados fossem diversos. Todavia, atualmente, reconhece a existência de litispendência:

No passado, entendíamos que não haveria litispendência na espécie, mas a posição externada em debates com a doutrinadora Patrícia Pizzol convenceunos de que há sim litispendência (....). ${ }^{31}$

A diferença quanto às pessoas dos autores não impede o reconhecimento da identidade de demandas e, por conseguinte, não traduzem qualquer impedimento ao reconhecimento da litispendência, sendo o polo passivo o mesmo.

\subsection{Identidade entre pedidos e/ou causa de pedir em ações coletivas - litispendência e reunião da ação}

Ao contrário da parcela da doutrina que entende pela necessidade de extinção da ação litispendente com fulcro no processo civil clássico, outros autores, por sua vez, defendem a necessidade da reunião das ações, mesmo estando presentes os elementos identificadores nas duas demandas, o que evidencia a litispendência. Fundamentam tal posição a partir da finalidade social do processo coletivo, bem como nos princípios que o regem.

Luiz Manoel Gomes Júnior, com razão, argumenta que "é impossível ignorar a existência de uma 'fobia' com relação às Ações Coletivas, contudo, os tempos são outros e tais tipos de demandas não podem ser analisados como se fossem demandas de natureza individual". ${ }^{32}$

Quando ocorrer a litispendência com partes diversas, a resolução da questão não pode ser a extinção de um dos processos, mas a reunião deles para processamento simultâneo. Afinal, "de nada adiantaria extinguir um dos processos, pois a parte autora, como co-legitimada, poderia intervir

${ }^{31}$ GOMES JUNIOR, Luiz Manoel. Curso de direito processual civil coletivo. 2. ed. São Paulo: Srs, 2008,p. 193.

32 GOMES JUNIOR, Luiz Manoel. Curso de direito processual civil coletivo. 2. ed. São Paulo: Srs, 2008, p. 190. 
no processo supérstite, na qualidade de assistente litisconsorcial." 33

Luiz Manoel Gomes Júnior também afirma que, havendo identidade de pedidos e causa de pedir entre ação popular e ação civil pública, os processos devem ser reunidos para decisão conjunta, não justificando a extinção pelo fenômeno da litispendência. Além disso, traz uma razão de ordem prática para aconselhar a adoção desse entendimento:

Poderia haver o ajuizamento de uma demanda mal proposta, o que impediria os demais legitimados de agir, enquanto não exista aquela apresentada em primeiro lugar, com inegáveis reflexos para os possíveis beneficiários com relação ao fator tempo. Em alguns casos, nem seria possível o aditamento, pois há o limite temporal (até a citação) [...] Seria até mesmo admissível, em tese, a criação de associações $a d$ hoc justamente com tal finalidade e, ajuizada determinada demanda, ficariam os demais legitimados impedidos de agir. ${ }^{34}$

José Miguel Garcia Medina e Teresa Arruda Alvim Wambier, ao enfrentarem o tema, reconhecem que as causas deverão ser reunidas para julgamento conjunto:

De qualquer forma, em casos como o ora analisado, notando-se que as sentenças a serem proferidas nas duas ações coletivas terão a mesma abrangência, deverão necessariamente as causas ser reunidas, para julgamento conjunto, nos termos acima referidos, sob pena de se criar um conflito prático intransponível. ${ }^{35}$

Marcelo Abelha Rodrigues questiona a possibilidade de ação popular proposta pelo cidadão ser extinta quando seus elementos forem rigorosamente idênticos aos de uma ação civil pública proposta por qualquer dos legitimados previstos em lei, vez que ambas estão constitucionalmente estabelecidas. Além disso, questiona-se a viabilidade, pois existe a necessidade de se prestigiar o amplo acesso à justiça:

Seria justo que a ação popular proposta pelo cidadão (ou assumida pelo MP, art. $9^{\circ}$ da Lei $4.717 / 65$ ) fosse extinta caso todos os elementos da demanda fossem rigorosamente idênticos aos de uma ação civil pública proposta por qualquer legitimado do art. $5^{\circ}$ da Lei 7.347/85? Poderia a lei impedir a participação política do cidadão, prevista no art. $5^{\circ}$, LXXIII, da $\mathrm{CF} / 88$, ou, em sentido

${ }^{33}$ DIDIER JUNIOR, Fredie; ZANETI JUNIOR, Hermes. Curso de direito processual civil: Processo coletivo. 3. ed. Bahia: Podivm, 2008, p. 180.

${ }^{34}$ GOMES JUNIOR, Luiz Manoel. Curso de direito processual civil coletivo. 2. ed. São Paulo: Srs, 2008, p. 195.

${ }^{35}$ MEDINA, José Miguel Garcia; WAMBIER, Teresa Arruda Alvim. Processo civil moderno: Parte Geral e Processo de Conhecimento. São Paulo: Revista dos Tribunais, 2010, p. 113. 
inverso, poderia a ação popular impedir a ação civil pública também prevista constitucionalmente (art. 129, $\S 3^{\circ}$ )? Afinal de contas, se a tutela jurisdicional coletiva deve ser a forma mais ampla de acesso à justiça, abrindo canais e portas de ingresso em juízo é justo, ou válido, ou legítimo, que se aplique para casos tais a extinção de uma das formas de participação da sociedade na tutela de direitos supra-individuais? $?^{36}$

Em casos tais, Teresa de Arruda Alvim Wambier leciona que o modelo articulado no Código de Processo Civil para a constatação de conexão e litispendência não serve para regular o confronto entre duas demandas coletivas, salvo se for aplicado de outro modo, observando as peculiaridades dessas ações. Com razão, afirma que "não é adequado aplicar integralmente e acriticamente critérios estabelecidos pelo CPC para a solução de ações individuais para dirimir dilemas relativos às ações coletivas." ${ }^{37}$

No mesmo sentido é a lição de Gregório Assagra de Almeida:

Com a devida vênia aos entendimentos em sentido contrário, entendemos que o fato de ser possível a ocorrência de litispendência (identidade) entre ação civil pública e ação popular ou entre outras ações coletivas não impõe e não pode impor a aplicabilidade fria e rígida do estabelecido no art. 267, V, do CPC. A extinção pura e simples com base nos efeitos negativos da litispendência de uma das ações coletivas poderá causar risco à efetiva tutela jurisdicional de direito coletivo. Imagine que a extinção venha a recair em relação a uma ação civil repleta de provas colhidas durante o inquérito civil. Nessas situações de ocorrência de litispendência entre ação civil pública e ação popular, o mais lógico e razoável é a aplicabilidade do que dispõe o CPC em seu artigo 105, com a reunião das respectivas ações coletivas para julgamento simultâneo em uma mesma sentença. ${ }^{38}$

Esse posicionamento funda-se no fato da sociedade de massa exigir do intérprete uma nova visão, posto que os instrumentos disponíveis surgiram em um momento em que o fenômeno dos conflitos de massa era socialmente menos incidente e, portanto, tornaram-se hoje insuficientes. ${ }^{39}$

Ademais, a distância que existe entre o resultado do processo e o aumento da valorização jurídica da cidadania motiva o surgimento de movimentos doutrinários que incentivam o aplicador das normas a

${ }^{36}$ RODRIGUES, Marcelo Abelha. Ação civil pública e meio ambiente. 2. ed. Rio de Janeiro: Forense Universitária, 2004, p. 142.

37 WAMBIER, Teresa Arruda Alvim. Litispendência em Ações Coletivas. In: MAZZEI, Rodrigo; NOLASCO, Rita Dias (Coord.). Processo civil coletivo. São Paulo: Quartier Latin, 2005, p. 289.

38 ALMEIDA, Gregório Assagra de. Manual das ações constitucionais. Belo Horizonte: Del Rey, 2007, p. 198.

39 RUFFOLO, Ugo. Interessi collettivi o difussi e tutela del consumatore. Milão: Giuffrè, 1985, p. 106. 
visualizá-las com características que retratem o verdadeiro valor da tutela jurisdicional, almejada pelo cidadão nas demandas postas em juízo. ${ }^{40}$

Cândido Rangel Dinamarco salienta que a efetividade do processo é evidenciada pela capacidade do sistema de produzir as situações de justiça realmente desejadas pela ordem social, política e jurídica. A tendência moderna do direito processual posiciona-se no sentido de conferir maior utilidade aos provimentos jurisdicionais. ${ }^{41}$

Ada Pellegrini Grinover anota com propriedade que é preciso repensar os institutos:

É preciso, antes de mais nada, que o processualista tenha a coragem intelectual de admitir que hoje aflora no processo situações diversas daquelas que constituíam o suporte dos institutos tradicionais. A tradição doutrinária não pode significar um obstáculo para repensar institutos. Que hão de ser moldados às novas situações. É preciso proceder, dentro de cada sistema, a uma análise funcional, ressaltando os tipos de interesses que devem ser protegidos e os tipos de provimentos idôneos à sua tutela, de modo a adaptar os mecanismos internos do processo à melhor consecução desses objetivos. Somente com essa mentalidade, poderá o processualista afeiçoar os velhos institutos às necessidades atuais, impulsionando, ao mesmo tempo, as reformas legislativas necessárias à tutela jurisdicional dos interesses difusos. ${ }^{42}$

É por isso que a reunião dos processos de natureza coletiva para serem julgados conjuntamente demonstra-se mais adequado, principalmente por propiciar o fortalecimento da proteção do interesse social contido nessas ações, e não a simples aplicação das normas estabelecidas no processo individual. Além disso, não restringe a possibilidade de defesa dos interesses em jogo por aquele que foi mais rápido na propositura da demanda, até porque nem sempre aquele que propõe primeiramente o fez de forma adequada e com densidade probatória para futura sentença de procedência. Tudo isso evidencia a possibilidade de, não reunindo os processos, acarretar sérios prejuízos à coletividade.

A reunião das demandas deve ocorrer ainda quando se almeja a tutela para direitos coletivos de diferentes espécies, ou seja, quando o mesmo caso ultrapassar a órbita dos direitos patrimoniais da população

${ }^{40}$ DELGADO, José Augusto. DELGADO, José Augusto. Interesses difusos e coletivos: Evolução Conceitual Doutrina e Jurisprudência do STF. Revista de Processo, São Paulo, v. 67, n. 98, p. 61-81, abr./jun. 2000, p. 61-62.

${ }^{41}$ DINAMARCO, Cândido Rangel. Instrumentalidade do processo. São Paulo: Revista dos Tribunais, 1990, p. 458.

42 GRINOVER, Ada Pellegrini. A problemática dos interesses difusos. In: GRINOVER, Ada Pellegrini (Coord.). A tutela dos interesses difusos. São Paulo: Max Limonad, 1984. p. 42-43 
diretamente afetada e atingir interesses metaindividuais, como o meio ambiente ecologicamente equilibrado e uma vida saudável.

Nesse caso, ainda que presentes direitos individuais homogêneos, a relevância social dos interesses em jogo é suficiente para autorizar o manejo concomitante de ação civil pública pelo legitimado ativo ${ }^{43}$.

As relações causais estão tão intimamente ligadas que um único fato pode provocar consequências de diferentes ordens, de modo que é presumível que dele advenham interesses múltiplos. É o caso, por exemplo, de um desastre ecológico que resulta em danos difusos ao meio ambiente, à saúde pública e, ao mesmo tempo, em danos individuais homogêneos aos residentes da região.

Dessa forma, as lides coletivas em que se pleiteiam direitos coletivos de diferentes espécies devem ser reunidas para evitar que a sentença proferida em uma delas não implique em contradição às outras.

O Superior Tribunal de Justiça solucionou o conflito de competência suscitado pela BRASIL TELECOM S/A (concessionária de serviço público de telefonia, que objetivava a definição do juízo competente para o julgamento de treze ações coletivas ajuizadas em diferentes seções judiciárias, relativas à tutela do mesmo bem jurídico), reunindo as ações:

PROCESSUAL CIVIL. CONFLITO DE COMPETÊNCIA. DEMANDAS COLETIVAS PROMOVIDAS CONTRA A ANATEL E EMPRESAS CONCESSIONÁRIAS DE SERVIÇO TELEFÔNICO FIXO COMUTADO. PRORROGAÇÃO DOS CONTRATOS DE CONCESSÃO. PRECEDENTES JURISPRUDENCIAIS. 1. Ações coletivas principais e cautelares e ação popular, cujo escopo último é de ação transindividual nas quais se discutem cláusulas contratuais e a possibilidade de prorrogação do contrato de concessão, todas emergentes do contrato-base, consoante às regras da Anatel, aplicáveis a todos os concessionários. 2. Decisões conflitantes exaradas com grave violação à uniformidade das decisões, bem como aos princípios constitucionais da isonomia e da segurança jurídica. 3. A potencialidade de decisões finais contraditórias, posto conexas as ações, viabilizando a repetição incalculável de ações com regramentos díspares para as mesmas situações jurídicas, recomendam a reunião das ações. 4. As decisões conflitantes proferidas são fatores suficientes a determinar a reunião das ações, porquanto os juízes, quando proferem decisões inconciliáveis, firmam as suas competências, fazendo exsurgir a conexão e a necessidade de reunião num só juízo, caracterizando o conflito de competência do artigo 115, III, do CPC. (precedentes) 5. O dano tem natureza nacional, por isso que incide na hipótese o artigo 93, II, do Código de Defesa do Consumidor (CC 39.590/RJ, Rel. Ministro Castro Meira, DJ 15.09.2003). 6. O ideal jurisdicional é a função preventiva do Judiciário em evitar a multiplicação das ações conducentes a resultados inconci-

${ }^{43}$ REsp 555.111/RJ, Rel. Min. Castro Filho, Terceira Turma, julgado em 5.9.2006, DJ 18.12.2006.) 
liáveis, o que ocorre in casu, em que se verifica que em cada ação há infirmação das regras básicas da Anatel, aplicáveis a todas as concessionárias, por isso que imperioso que em unum et idem judex dê-se uma única solução para todas, tanto mais que o que caracteriza a conexão é a comunhão do objeto mediato do pedido, no caso sub judice, o modelo contratual de concessão em si, por isso que as ações revelam os seguintes pedidos a saber: [...] 7. A Corte Especial, percorrendo o mesmo raciocínio diante de ações individuais e coletivas que se voltavam contra a prorrogação dos contratos de concessão com a Anatel, decidiu em suspensão de segurança confirmada pelo AgRg na SLS 250-MS, que antevendo a conexão e a possibilidade de decisões contraditórias deve haver a reunião das ações no foro do Distrito Federal se o suposto dano é nacional. 8. A continência é uma espécie de conexão por que a infirmação do contrato no seu todo ou de algumas cláusulas implica assentar que a pretensão se volta contra a prorrogação total ou parcial do vínculo. 9. Por fim, a decisão que altera contratos de concessão com a Anatel apenas em relação a algumas operadoras, restando incólume o vínculo em relação às demais, viola o princípio constitucional da isonomia, além de propiciar decisões contraditórias e repetição avassaladora de ações. 10. O conflito de competência, em regra, não ostenta caráter prospectivo para incluir no Juízo conexo eventuais ações futuras. 11. Ressalva do ponto de vista do Relator porquanto à luz do entendimento a contrario sensu, as ações instauradas após o conflito e ainda não julgadas devem ser submetidas ao unum et idem judex, cumprindo as finalidades do instituto que é a de evitar, a qualquer tempo, decisões contraditórias. Deveras, na Reclamação 2.259-PA, no voto-vista proferido pelo E. Ministro João Otávio de Noronha, assentou-se que nas ações com escopos transindividuais, o Juízo deve ser sempre universal. 12. Inviabilidade do atendimento da pretensão da suscitante relativamente às eventuais ações conexas a serem propostas, já que o referido pleito não se subsume ao disposto no art. 115 do CPC, razão pela qual nesta parte vencido o E. Relator, que admite a prevenção do juízo para as ações futuras até que o juízo prevento mantenha a sua competência. 13. Conflito de competência conhecido para firmar a competência do Juízo Federal prevento pela propositura da

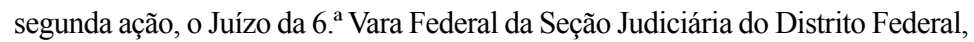
tendo em vista a extinção sem resolução do mérito da primeira ação (Súmula 235 do STJ), na forma do disposto nos artigos 109, I, da CF/1988 c.c. artigo 93, II, do CDC c.c. artigo 2. ${ }^{\circ}$ § único da Lei 7.347/85, excluídas as ações conexas que venham a ser propostas. (precedentes: CC 39.063-PE, Rel. Min. LUIZ FUX, DJ 29.03.2004; AgRg no CC 58.229-RJ, Rel. Min. JOÃO OTÁVIO DE NORONHA, DJ 05.06.2006; EDcl no CC 403-BA, Rel. Min. ANTÔNIO TORREÃO BRAZ, DJ 13.12.1993; CC 41.444-AM, Rel. Min. LUIZ FUX, DJ 16.02.2004; CC 39.590-RJ, Rel. Min. CASTRO MEIRA, DJ 15.09.2003. ${ }^{44}$

Perceba-se que as múltiplas ações coletivas mencionadas nesse aresto foram tratadas como conexas, decidindo-se, assim, pela reunião de tais demandas em um só juízo.

${ }^{44}$ STJ. C.C. No 57.558 - DF (2005.0215616-5). Rel. Ministro Luiz Fux, Primeira Seção, j. 12/09/2007, DJ. 03/03/2008. 
Observe que em todas as demandas envolvidas se buscavam a tutela de direitos do consumidor, diante da insurgência contra a assinatura da prorrogação dos contratos de telefonia fixa comutada e das disposições ali contidas. Tal fato justifica a reunião das ações, principalmente perante o risco de decisões contraditórias se julgadas separadamente.

Importante destacar os argumentos do Ministro Luiz Fux, que em seu voto enfatizou:

A grande realidade é saber se podemos conviver com nossa função, tal como prevista na Constituição Federal, assistindo passivamente, chegarem aqui cem mil ações com decisões diferentes sobre a mesma matéria. Isso significa abdicar do dever de velar pela cláusula máxima consectária da tutela da dignidade da pessoa humana, que é a igualdade. Sabemos que um dos fatores que levou o Poder Judiciário a um profundo descrédito perante a opinião pública foi a falta de sintonia nas decisões. Citei uma vez um exemplo: um leigo pergunta para um outro qual é o juiz dele, pensando que poderia ir ao juiz do outro e conseguir o mesmo que o outro conseguiu, porque não conhece o princípio do juízo natural. No meu modo de ver, a conexão é inegável. Aliás, o Sr. Ministro Teori Albino Zavascki entende que elas são conexas. Além do mais, não estamos julgando litígios individuais, mas uma discussão relativa a um ato-base genérico, que é o ato da agência que intervém quando instituiu a tarifa básica, sem considerarmos alguns aspectos práticos de que, se isso eventualmente vier a surpreender as partes em conflito, certamente essas empresas - e temos assistido a isso com constância na Corte Especial - reclamarão na Corte Especial para fazer valer a condição originária da concessão, sob pena de repassar para o consumidor, num tiro às avessas, a onerosidade pela impossibilidade de cobrar a tarifa básica que a agência reguladora autorizou (...) Esta é uma ação coletiva, que versa e que interessa a todos. Uma ação dessa tem gerado a repetição de inúmeras ações. Nossa opção na vida é: ira ou amor. Temos que fazer uma opção. Vamos receber cem mil ações, cada uma com uma decisão diferente e vamos bater no peito que somos um tribunal da cidadania, mas violando a isonomia, ou daremos uma solução para essa questão, que é nacional? Diante desse panorama, reformulando meu voto, já que entendo que não podem permanecer nos juizados especiais, assento que a ratio essendi da conexão das ações coletivas é manter a uniformidade das decisões, do contrário, estaremos criando, com as ações coletivas, a possibilidade de decisões contraditórias, isto é, estamos indo na contramão da finalidade do instituto. Sugiro que todas as ações sejam reunidas no juízo federal para uma decisão única, porque, mesmo aquela primeira solução de grupos ficarem em locais diferentes, gera a possibilidade de essas decisões serem contraditórias nesses grupos. Essa é a complementação da minha sugestão de voto. ${ }^{45}$

Essa decisão leva em conta o princípio da segurança jurídica, o respeito

${ }^{45}$ STJ. C.C. No 57.558 - DF (2005.0215616-5). Rel. Ministro Luiz Fux, Primeira Seção, j. 12/09/2007,DJ. 03/03/2008. 
ou desrespeito aos contratos, e até mesmo o risco de descontinuar serviço público essencial a todos os brasileiros, como é o caso da telefonia fixa.

José Roberto dos Santos Bedaque leciona que: "a natureza instrumental do direito processual impõem sejam seus institutos concebidos em conformidade com as necessidades do direito substancial". E continua, "a eficácia do sistema processual será medida em função de sua utilidade para o ordenamento jurídico material e para a pacificação social”"46.

\section{Considerações finais}

A evolução da sociedade e a massificação dos conflitos evidenciaram a necessidade de inovações no direito processual brasileiro, sob pena de perder sua eficácia social. As regras contidas no processo civil clássico para tutelar os direitos individuais não se mostraram adequadas quando estiveram em disputa direitos transindividuais, entendidos como aqueles que repercutem na esfera individual de um grande número de pessoas, muitas vezes não identificáveis, como no caso do direito a um meio ambiente sadio.

Os institutos da litispendência e conexão no âmbito coletivo, foco principal desse estudo, tiveram seus conceitos extraídos do processo individual, diante da omissão do microssistema coletivo.

A doutrina se divide ao apresentar soluções. Alguns entendem que, se ocorrer identidade entre as partes, causa de pedir e pedidos, deve ser reconhecida a litispendência, com a consequente extinção do processo ajuizado posteriormente. Todavia, assegura que esse posicionamento não tem validade se as partes forem diversas.

Esse posicionamento recebe severas críticas, pois não há dúvidas que em se tratando de demanda onde se pleiteia Direito Coletivo não há que ser levado em conta a figura do autor para fins de reconhecimento de identidade de ações, já que o autor, em tais casos, atua como verdadeiro substituto processual, pleiteando não em direito próprio, mas direito alheio, direito de toda a coletividade.

Outra parcela da doutrina assevera que as ações coletivas ajuizadas com igualdade de elementos, ainda que por entes diversos, deve ser extinta com fundamento na litispendência, vez que a coletividade já está sendo representada em juízo.

No entanto, a extinção do processo litispendente ofenderia o direito

${ }^{46}$ BEDAQUE, José dos Santos. Direito e processo: influência do direito material sobre o processo.

2. ed. 2. tir. São Paulo: Malheiros, 2001, p. 16. 
fundamental de acesso ao judiciário, como estabelecido no artigo $5^{\circ}$, XXXV, da Constituição Federal. Ademais, há uma razão de ordem prática: evitar o ajuizamento de uma demanda mal proposta com o escopo de impedir os demais legitimados de agir.

Ao contrário das correntes que exigem a extinção da ação litispendente com fulcro no processo civil clássico, a posição doutrinária que mais se coaduna com a finalidade social do processo coletivo é aquela que permite a reunião das ações para julgamento conjunto, aproveitando as provas e argumentos apresentados nas diversas ações. Esse posicionamento não busca unicamente perfeição científica, mas também a máxima eficiência e facilidade de aplicação. Além disso, as peculiaridades situadas no plano substancial impõem a adoção de técnicas diversas, sem o que não é possível atingir os resultados desejados pelo sistema.

\section{Lis pendens and connection in the brazilian collective process}

Abstract: This paper aims to study the effects of lis pendens and connection within the collective process. These institutes were created in the light of the classic civil procedure, eminently individualistic, which generates controversy and makes their study complex, especially for not being in accordance with the specific principles and the need for an effective process. After the analysis of the doctrine and jurisprudence, was shown the necessity of meeting actions for the use of evidence voided and the legal situation, providing extensive access to justice.

Keywords: Collective Action. Lis pendens. Connection.

\section{REFERÊNCIAS}

ALMEIDA, Gregório Assagra de. Manual das ações constitucionais. Belo Horizonte: Del Rey, 2007.

BEDAQUE, José dos Santos. Direito e processo: influência do direito material sobre o processo. 2. ed. 2. tir. São Paulo: Malheiros, 2001.

CARVALHO FILHO, José dos Santos. Ação civil pública: Comentários por artigo (Lei $n^{\circ} 7.347$, de 24/7/85). 7. ed. Rio de Janeiro: Lumen Juris, 2009. 
CHIOVENDA, Giuseppe. Instituições de direito processual civil. Tradução de Paolo Capitanio. 2. ed. Campinas: Bookseller, 2000. v. 1. CORREIA, André de Luizi. A citação no direito processual civil brasileiro. São Paulo: Revista dos Tribunais, 2001.

DELGADO, José Augusto. Interesses difusos e coletivos: Evolução Conceitual Doutrina e Jurisprudência do STF. Revista de Processo, São Paulo, v. 67, n. 98 , p. 61-81, abr.jun. 2000.

DIDIER JUNIOR, Fredie; ZANETI JUNIOR, Hermes. Curso de direito processual civil: Processo coletivo. 3. ed. Bahia: Podivm, 2008.

DINAMARCO, Cândido Rangel. Instrumentalidade do processo. São Paulo: Revista dos Tribunais, 1990.

DINAMARCO, Pedro da Silva. Competência, conexão e prevenção nas ações coletivas. In: MILARÉ, Edis (Coord.). Ação civil pública após 20 anos: efetividade e desafios. São Paulo: Revista dos Tribunais, 2005. GIDI, Antonio. Coisa julgada e litispendência em ações coletivas. São Paulo: Saraiva, 1995.

GRINOVER, Ada Pellegrini. A problemática dos interesses difusos. In: GRINOVER, Ada Pellegrini (Coord.). A tutela dos interesses difusos. São Paulo: Max Limonad, 1984.

GOLDSCHIMIDT, James. Direito processual civil. Tradução de Lisa Pary Scarpa. Campinas: Brookseler, 2003. tomo I.

GOMES JUNIOR, Luiz Manoel. Curso de direito processual civil coletivo. 2. ed. São Paulo: Srs, 2008

LIEBMAN, Enrico Tullio. Manual de direito processual civil. Tradução de Cândido Rangel Dinamarco. 3. ed. São Paulo: Malheiros, 2005. v. 1 .

MANCUSO, Rodolfo de Camargo. Divergência jurisprudencial e súmula vinculante. São Paulo: Revista dos Tribunais, 1999.

MARINONI, Luiz Guilherme; ARENHART, Sérgio Cruz. Manual do Processo de Conhecimento. 2. ed. São Paulo: Revista dos Tribunais, 2003. 
MARQUES, José Frederico. Instituições de direito processual civil. Rio de Janeiro: Forense, 1958. v. 3.

MEDINA, José Miguel Garcia; WAMBIER, Teresa Arruda Alvim. Processo civil moderno: Parte Geral e Processo de Conhecimento. São Paulo: Revista dos Tribunais, 2010.

NEVES, Daniel Amorim Assumpção. Manual de processo civil. 2. ed. São Paulo: Método, 2010.

RODRIGUES, Marcelo Abelha. Ação civil pública e meio ambiente. 2. ed. Rio de Janeiro: Forense Universitária, 2004.

RUFFOLO, Ugo. Interessi collettivi o difussi e tutela del consumatore. Milão: Giuffrè, 1985.

THEODORO JÚNIOR, Humberto. Curso de direito processual civil. 42. ed. Rio de Janeiro: Forense, 2005. v. 1.

TORNAGHI, Hélio. Comentários ao código de processo civil. São Paulo: Revista dos Tribunais, 1974.

VENTURI, Elton. Processo civil coletivo: A tutela jurisdicional dos direitos difusos, coletivos e individuais homogêneos no Brasil. Perspectivas de um Código Brasileiro de Processos Coletivos. São Paulo: Malheiros, 2007.

WAMBIER, Teresa Arruda Alvim. Litispendência em Ações Coletivas. In: MAZZEI, Rodrigo; NOLASCO, Rita Dias (Coord.). Processo civil coletivo. São Paulo: Quartier Latin, 2005.

WAMBIER, Luiz Rodrigues; TALAMINI, Eduardo. Curso avançado de processo civil: Teoria Geral do Processo e Processo de Conhecimento. 11. ed. São Paulo: Revista dos Tribunais, 2010.

WATANABE, Kazuo. Demandas coletivas e os problemas da práxis forense. Revista de Processo, São Paulo, n. 67, jul./set. 1992.

Recebido: março/2011. Aprovado: abri1/2013. 